\title{
RANKING STRATEGIC AND OPERATIVE GOALS FOR SUSTAINABLE DEVELOPMENT OF POHORJE, SLOVENIA
}

\author{
RAZVRŠČANJE STRATEŠKIHI IN OPERATIVNIH CILJEV TRAJNOSTNEGA \\ RAZVOJA POHORJA, SLOVENIJA
}

\author{
Petra GROŠELJ ${ }^{1}$, Lidija ZADNIK STIRN² ${ }^{2}$, Gregor DANEV ${ }^{3}$, Darij KRAJČIČC ${ }^{4}$ \\ (1) Univerza v Ljubljani, Biotehniška fakulteta, Oddelek za lesarstvo, 1000 Ljubljana, SLO, petra.groselj@bf.uni-lj.si \\ (2) Univerza v Ljubljani, Biotehniška fakulteta, Oddelek za gozdarstvo in obnovljive gozdne vire, 1000 Ljubljana, SLO, \\ lidija.zadnik@bf.uni-lj.si \\ (3) Zavod RS za varstvo narave, vodja projekta NATREG, 1000 Ljubljana, SLO, gregor.danev@zrsvn.si \\ (4) Zavod RS za varstvo narave, 1000 Ljubljana, SLO, zrsvn.oe@zrsvn.si
}

\begin{abstract}
The combination of participatory process and multi-criteria decision methods have proven to be effective in supporting forest management decisions, since it offers inclusion of different opinions, views, and preferences of the problem. Our study is based on the results of the NATREG project, which deals with management of Pohorje, a mountain area in Slovenia. The results define six strategic goals and appertaining operative goals, which are the outcomes of workshops with different stakeholders. The aim of our study is ranking the strategic goals according to their contribution in the implementation of the "Pohorje 2030" vision and of the operative goals according to the appertaining strategic goals. Analytic hierarchy process is applied for comparisons of goals. Geometric mean method is employed for aggregating individual judgments into group judgment. The results show that all strategic goals are important, although most attention should be devoted to the goals "Preserved cultural heritage and local tradition" and "Environmental and consumer friendly usage of natural resources".
\end{abstract}

Key words: analytic hierarchy process, group decision-making, sustainable development, natural resources, forest management

\begin{abstract}
IZVLEČEK
Kombinacija participatornega vključevanja deležnikov v proces odločanja in večkriterijskih metod se je pri gospodarjenju z gozdom izkazala za uspešno, saj ponuja možnost vključevanja različnih mnenj, pogledov in preferenc problema. Osnova naše raziskave je projekt NATREG, ki je potekal na Pohorju v Sloveniji in v okviru katerega so določili šest strateških ciljev in pripadajoče operativne cilje. Cilj raziskave je razvrstitev strateških ciljev glede na njihov prispevek k uresničitvi vizije »Pohorje 2030 « in operativnih ciljev glede na pripadajoči strateški cilj. Za primerjavo ciljev smo uporabili metodo analitičnega hierarhičnega procesa. Individualne ocene smo združili v skupno oceno z geometrijsko sredino. Rezultati kažejo, da so pomembni vsi strateški cilji, najbolj pa »Ohranjena kulturna dediščina in lokalna izročila« in »Okolju in uporabniku prijazna raba naravnih virov«.
\end{abstract}

Ključne besede: analitični hierarhični proces, skupinsko odločanje, trajnostni razvoj, naravni viri, gospodarjenje z gozdom

GDK 611+906+91(497.4Pohorje)(045)=163.6

Prispelo / Received: 17. 12. 2012

Sprejeto / Accepted: 15. 05. 2013

\section{INTRODUCTION}

1 UVOD

Traditionally, forest management has emphasized optimizing timber production and the associated financial returns. More recently, the natural, cultural, ecological and social values of forests have been targeted by resource management planning. Therefore, sustainable approaches that will protect environmental values and incorporate all forest functions in management decisions are needed (Sheppard in Meitner, 2005).
Different views and preferences can be included in the problem through different stakeholders. The participation of stakeholders is very important for a more complete view of the problem. When maximizing timber production was the only goal, the only decision maker was often the owner of the forest. In participatory planning, different interests, views and preferences can be represented by interested organizations, groups, or individuals: forest owners, governmental institutions, non-governmental organizations, local communities (Rowe in Frewer, 2000). The participato- 
ry inclusion of stakeholders has been applied in many forest management cases (Ananda in Herath, 2003; Nordström in sod., 2010; Nordström in sod., 2009).

The combination of participatory process and multi-criteria decision methods have proven to be effective, since it offers the reconciliation and consideration of different opinions, views, preferences, and circumstances of the problem (Bryan in sod., 2010; Mendoza in Prabhu, 2006; Pavlikakis in Tsihrintzis, 2003). The main benefit of multi-criteria decision methods is the formal model, which assures transparency. They also help by structuring the problem and allowing conflict, unpredictability, subjectivity, and values comparison to be included on similar scales (Belton in Stewart, 2002).

Multi-criteria decision making models are well developed and have been employed in many applications (Ananda in Herath, 2009; Diaz-Balteiro in Romero, 2008; Weintraub in sod., 2007) The Analytic Hierarchy Process (AHP) (Saaty, 1980) is a widely used method for solving multiple criteria decision making problems. Its main goal is ranking, selecting and evaluating the hi-

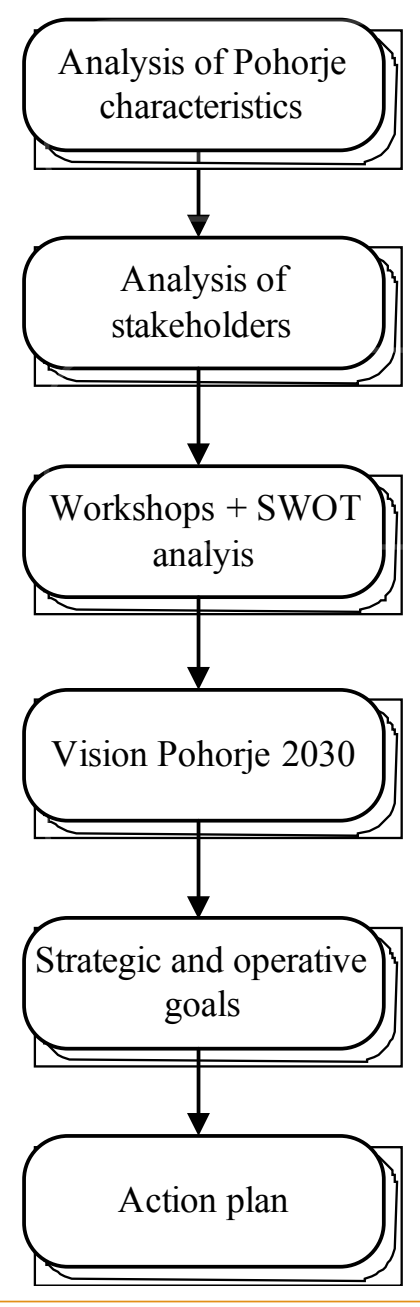

Fig 1: The scheme of NATREG project Slika 1: Shema projekta NATREG erarchy of criteria and alternatives. AHP has also been recognized as a useful tool in the field of natural resource management (Blackstock in sod., 2007). It has been employed in sustainable development (Srdjevic in sod., 2007), environmental management (Carpenter in sod., 2009; Costanza, 2006; Zendehdel in sod., 2008) and forest management problems (Kangas in Kangas, 2005; Sheppard in Meitner, 2005; Wolfslehner in Seidl, 2010).

Pohorje, a highland in Slovenia, is mostly covered with conifer forests. $70 \%$ of forests are private property. Due to impermeable ground, characteristic peaty bogs were formed. The forests provide habitats for numerous rare and endangered bird species. The structure of tree species was changed on more than half of the area, where beech is replaced by spruce. The forests stress ecological function on $90 \%$ of the area, social functions on $47 \%$ of the area and production functions on $74 \%$ of forest area (Cenčič, 2010). Pohorje is under the protection of the Alpine convention and a large part of Pohorje is part of the Natura 2000 network. Besides forestry, economic development of Pohorje is mostly connected with tourism. Pohorje is a popular recreational center with alpine and crosscountry skiing in the winter, and trekking and cycling in the summer. Agriculture is also practiced along the edge of Pohorje, but it is not particularly profitable. Supplementary activities, especially in connection with tourism, are becoming more and more important.

The main drawback for Pohorje development is a lack of common vision and goals. There is no connection between sectors, suppliers, and local people. Everyone tries to realize his own ideas. To surpass these problems, the NATREG (NATREG, 2011b) project was implemented in Pohorje. The scheme of the project is presented in Figure 1. First analysis of Pohorje was conducted. Studies of sector plans, demographic, climate, geomorphic, ecological and biological characteristics were performed. Forestry, hunting, fishing, agriculture, tourism, water management, nature and environment protection, natural and cultural heritage were analyzed (Borec in sod., 2010; Cenčič, 2010; Lešnik Štuhec, 2010). Then, ecological, socio-cultural and economic values of Pohorje were evaluated. In the second step, the analysis of stakeholders has been performed. The key stakeholders were determined: public entities (municipalities, development agency, chamber, educational institutions, public institutions, institutes and ministry) and private entities (tourism, forestry and agriculture, education and protection of nature). The stakeholders were first invited to the sector workshops, and then to the joint workshop, where 


\begin{tabular}{|c|c|}
\hline Strategic goals & Operative goals \\
\hline \multirow{4}{*}{$\begin{array}{l}\text { High quality life of } \\
\text { locals }\left(s_{1}\right)\end{array}$} & $\begin{array}{l}\text { Connected, adjusted and responsible activities between all interested stakeholders with the purpose of } \\
\text { joint development and promotion of the area (011) }\end{array}$ \\
\hline & Connection of local people and their involvement in the area's management and development (012) \\
\hline & $\begin{array}{l}\text { Specialized education to increase the knowledge and the skills of the locals, and learning campaigns } \\
\text { (o13) }\end{array}$ \\
\hline & Provided and well established residence infrastructure (014) \\
\hline \multirow{8}{*}{$\begin{array}{l}\text { Preserved nature } \\
\text { and landscape }\left(\mathrm{s}_{2}\right)\end{array}$} & Restored and preserved Pohorje plains (021) \\
\hline & Restored and preserved water system in Pohorje swamps and waters (022) \\
\hline & $\begin{array}{l}\text { Preserved high forest cover with special purpose (virgin forests, forest reserves, protective forests) and } \\
\text { establishment of the eco cells network (023) }\end{array}$ \\
\hline & $\begin{array}{l}\text { Working and effective system for monitoring conditions of species and habitat types in Natura } 2000 \\
\text { areas }(024)\end{array}$ \\
\hline & Restored effective control of nature protection for activities in Pohorje (025) \\
\hline & Establishment of a wider protected area -Pohorje Park (026) \\
\hline & Active fund for nature protection in Pohorje (027) \\
\hline & Preserved landscape patterns of Pohorje (028) \\
\hline \multirow{5}{*}{$\begin{array}{l}\text { Sustainable tourism } \\
\text { and limited visits }\left(\mathrm{s}_{3}\right)\end{array}$} & Restored conditions for comprehensive experience of Pohorje's nature and cultural heritage (031) \\
\hline & Identified brand of sustainable destination Pohorje (032) \\
\hline & Locally conditioned and zoned sustainable capacities and activities in Pohorje (033) \\
\hline & Quality and coordinated supply of local products (034) \\
\hline & Established organization of sustainable destination Pohorje (035) \\
\hline \multirow{7}{*}{$\begin{array}{l}\text { Environmentally and } \\
\text { consumer friendly } \\
\text { usage of natural } \\
\text { resources }\left(\mathrm{s}_{4}\right)\end{array}$} & $\begin{array}{l}\text { Realized cut of timber, allowed by forests management plans and reduction of overgrown areas and } \\
\text { restored traditional agricultural use of Pohorje plains (041) }\end{array}$ \\
\hline & Increased agricultural activity (042) \\
\hline & $\begin{array}{l}\text { Increased and effective use of local natural materials for building purposes and as natural sources of } \\
\text { food }(043)\end{array}$ \\
\hline & $\begin{array}{l}\text { Increased use of energy from available renewable natural resources (biomass, sun, wind) and effective } \\
\text { use of energy (044) }\end{array}$ \\
\hline & Development of products from local natural resources and brands with name Pohorje (045) \\
\hline & Motivated and qualified producers of products from natural resources (0046) \\
\hline & $\begin{array}{l}\text { Environment-friendly and sustainable use of water and water supply as a source of drinkable water } \\
(047)\end{array}$ \\
\hline \multirow{3}{*}{$\begin{array}{l}\text { Environmentally and } \\
\text { consumer friendly } \\
\text { mobility and good } \\
\text { infrastructure }\left(\mathrm{s}_{5}\right)\end{array}$} & Accepted and implemented interregional and local plans for traffic connections (051) \\
\hline & Modernized and maintained traffic infrastructure and quality public traffic (052) \\
\hline & $\begin{array}{l}\text { Good traffic connections for visitors from lowland to the tourist centres with alternative kinds of tran- } \\
\text { sport (053) }\end{array}$ \\
\hline \multirow{3}{*}{$\begin{array}{l}\text { Preserved cultural } \\
\text { heritage and local } \\
\text { tradition }\left(\mathrm{s}_{6}\right)\end{array}$} & $\begin{array}{l}\text { Preservation of the local architecture characteristics and restoration of an effective system of advi- } \\
\text { sing, stimulations, supervision and regulations (061) }\end{array}$ \\
\hline & Taking advantage of the potentials for development of cultural heritage and local tradition (062) \\
\hline & Linked local and regional events linked with cultural heritage (063) \\
\hline
\end{tabular}

SWOT analysis of sectors and joint SWOT analysis, respectively, were performed (Uratarič in Marega, 2010).

This scheme was the basis for the "Pohorje 2030" vision (Hojnik, 2011). Based on this vision, the NATREG project group defined six strategic goals and appertaining operative goals, which were presented to the stakeholders at the workshops. They added their opinions and suggestions, which were incorporated in the goals. Final strategic and operative goals are presented in Table 1. These goals generated the action plan of the feasible projects.

The main contribution of our paper is to assess, which goal can contribute most to the realization of the "Pohorje 2030" vision. Thus, the aim of our study, which supplements the NATREG project, is ranking of the strategic goals according to the "Pohorje 2030" 


\begin{tabular}{|c|l|}
\hline Value $a_{\mathfrak{j}}$ & \\
\hline 1 & Elements $\mathrm{i}$ and $\mathrm{j}$ are equally important. \\
\hline 3 & Element $\mathrm{i}$ is slightly more important than element $\mathrm{j}$. \\
\hline 5 & Element $\mathrm{i}$ is much more important than element $\mathrm{j}$. \\
\hline 7 & Element $\mathrm{i}$ is proved to be more important than element $\mathrm{j}$. \\
\hline 9 & Element $\mathrm{i}$ is absolutely more important than element $\mathrm{j}$. \\
\hline $2,4,6,8$ & Middle values \\
\hline
\end{tabular}

vision and operative goals according to the strategic goals.

The paper is formulated as follows. First, in Section 2 , we review the AHP method. In section 3, we provide the results of ranking strategic and operative goals of Pohorje development. In Section 4, the main conclusions are presented.

\section{METHODS}

\section{METODE}

Analytic hierarchy process's core idea is pairwise comparisons of elements on the same level of hierarchy regarding the element on the next level of hierarchy. Estimations from the fundamental scale of the AHP (Saaty, 2006) (Table 2) are employed for pairwise comparisons and a reciprocal values are assigned to the inverse comparisons, i. e. . Such method enables comparisons of tangible and intangible, of empirical data and subjective judgments.

The inconsistency of matrix of all pairwise comparisons $A=\left(a_{i j}\right)_{n \times n}, i, j=1, \ldots, n$, is measured by consistency ratio

$$
C R_{A}=\frac{C I_{A}}{R I_{n}}
$$

where $C I_{A}=\frac{\lambda_{A, \max }-n}{n-1}$ is consistency index, $\lambda_{A \text {, max }}$ is the maximal eigenvalue of matrix $A$, and $R I_{n}$ is random index (Table 3 ).

Matrix $A$ is acceptably consistent if $C R_{A}<0.1$.

Priority vector $w=\left(w_{1}, \ldots, w_{n}\right)$ is derived from the matrix $A$ by the eigenvector method:

$$
A w=\lambda_{A, \max } w
$$

where $w$ is the eigenvector, belonging to the maximal eigenvalue of $A$.

In the event of more than one stakeholder, their judgments can be aggregated into the group judgment applying geometric mean method (GMM). Let $a_{i j}^{k}$ , $k=1, \ldots, m$ be judgments of $m$ stakeholders. Then the group judgment is a geometric mean of all individual judgments:

$$
a_{i j}^{\text {group }}=\sqrt[m]{\prod_{k=1}^{m} a_{i j}{ }^{k}}
$$

The group priority vector can be derived from the group comparison matrix $A^{\text {group }}=\left(a_{i j}^{\text {group }}\right)_{n \times n}$ by the eigenvector method. GMM is suitable since it preserves reciprocal property of the group comparison matrix $A^{\text {group }}$. If stakeholders are not equally important, weighted geometric mean can be used. This group method has been used in many applications (Ananda in Herath, 2008; Cortés-Aldana in sod., 2009; Duke in Aull-Hyde, 2002; Lee in sod., 2009; Sun in Li, 2009; Wang in Chin, 2009).

\section{RESULTS AND DISCUSSION}

\section{REZULTATI IN RAZPRAVA}

We set up the hierarchical tree of goals (Figure $2)$. For evaluation of pairwise comparisons, we selected five experts who also contributed to the NATREG project. They compared operative goals according to the appertaining strategic goal and strategic goals according to the general goal of the problem/model. We checked that all comparison matrices were acceptably

Preglednica 3: Preglednica random indeksov $R I_{n}$ (Saaty, 2006)

Table 3: Table of random index $R I_{n}$ (Saaty, 2006)

\begin{tabular}{|c|c|c|c|c|c|c|c|c|c|c|c|c|c|c|c|}
\hline $\mathrm{n}$ & 1 & 2 & 3 & 4 & 5 & 6 & 7 & 8 & 9 & 10 & 11 & 12 & 13 & 14 & 15 \\
\hline $\mathrm{RI}$ & 0 & 0 & 0.52 & 0.89 & 1.11 & 1.25 & 1.35 & 1.40 & 1.45 & 1.49 & 1.51 & 1.54 & 1.56 & 1.57 & 1.58 \\
\hline
\end{tabular}




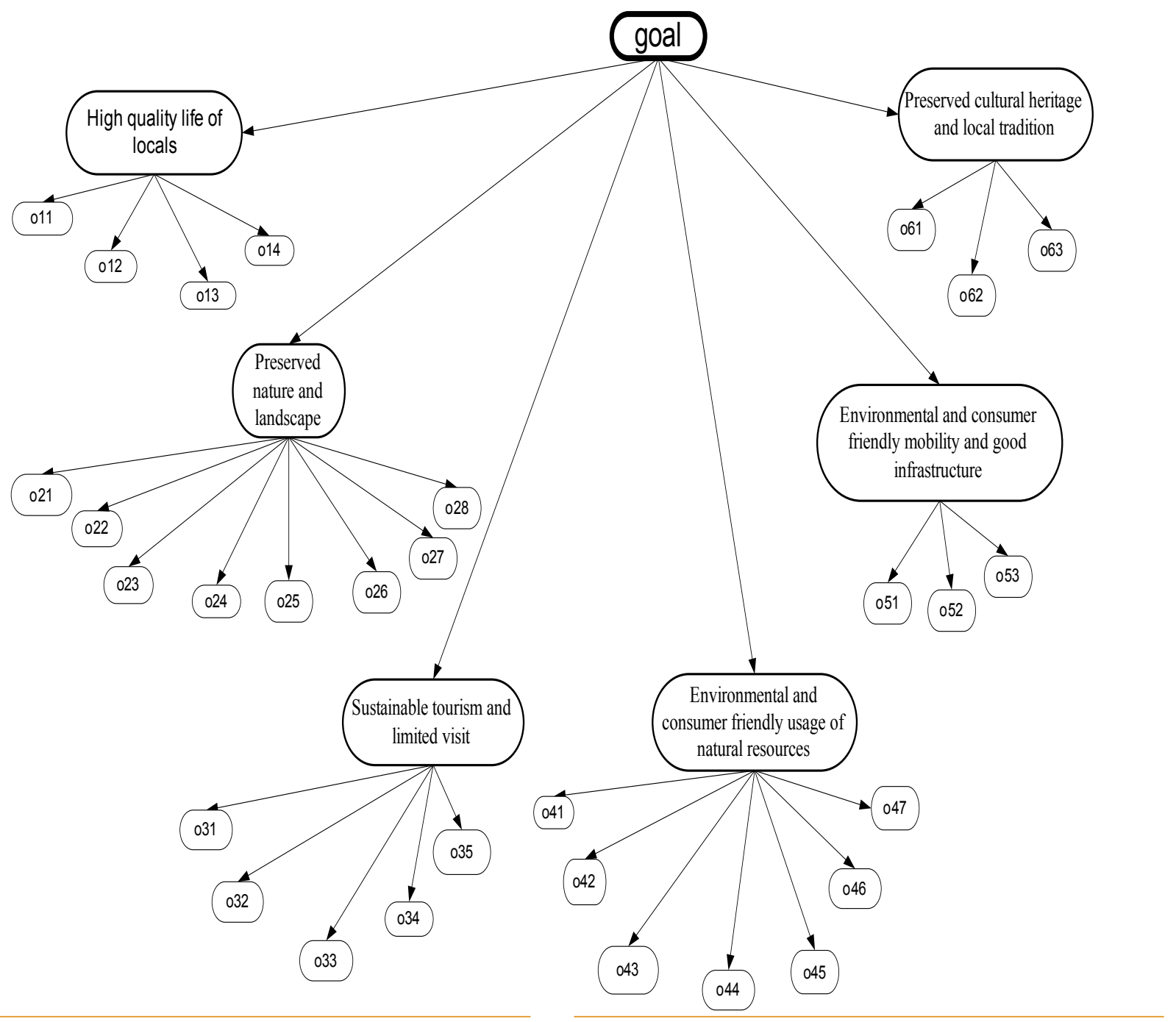

Fig. 2: Hierarchical structure of goals

consistent. We assumed that all decision makers were equally important and applied GMM for aggregation of individual judgments. We employed the eigenvector method for deriving the priority vectors from group comparison matrices. Derived group priority vectors are presented in Table 4. Second column in Table 4 shows the weights of strategic goals, while the fourth column shows the weights of operative goals. The fifth column shows ranking of the operative goals according to the appertaining strategic goals.

Weights of strategic goals are presented in the polar graph (Figure 3).

Results show that the most important strategic goal is "Preserved cultural heritage and local tradition" with the weight of 20.5\%. The goal "Environmental and consumer friendly usage of natural resources" was placed second with the weight of $18.1 \%$. Then goals with similar weights follow: "Preserved nature and landscape", "High quality life of the locals" and "Sustainable tourism and limited visit". The smallest weight, i.e. 13.3\%, was given to the goal "Environmental and consumer
Slika 2: Hierarhična struktura ciljev

friendly mobility and good infrastructure". Difference between the first ranked and the last ranked strategic goals is only $7 \%$, which means that it is important to fulfil all strategic goals in order to realize the "Pohorje 2030" vision.

Regarding the strategic goal "High quality life of locals", we can see that all four operative goals have similar weights. The highest weight was given to the operative goal "Connection of local people and their involvement in management and development of area", which is followed by "Specialized educations to increase knowledge and skills of the locals, and learning campaigns", then by the operative goal "Connected, adjusted and responsible activity between all interested stakeholders with the purpose of joint development and promotion of the area", and finally by the operative goal "Provided and well established residence infrastructure".

When analyzing the strategic goal "Preserved nature and landscape", we see that the most important operative goal is the "Establishment of wider protect- 


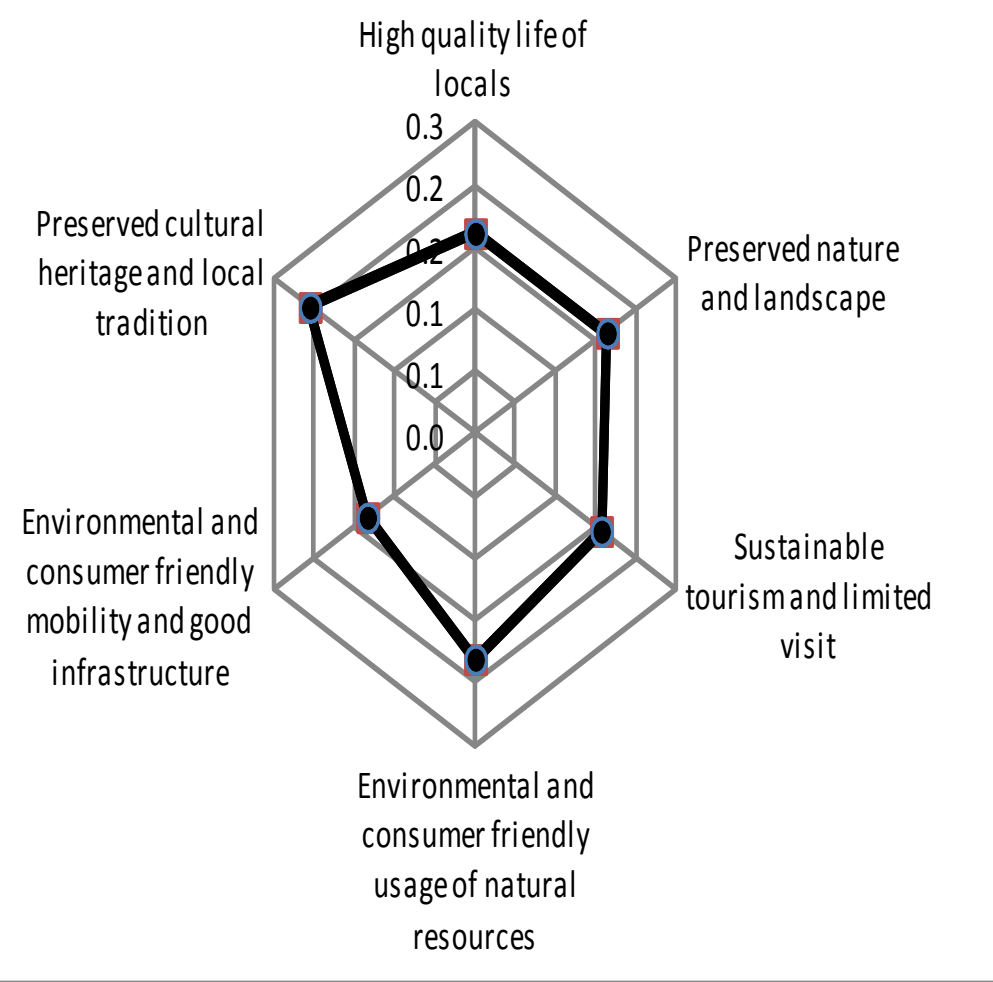

Fig. 3: Priorities of strategic goals

ed area-Pohorje Park" with $18.5 \%$. Its weight is much higher than the weight of the operative goals "Working and effective system for monitoring conditions of species and habitat types in Natura 2000 areas" (13.4\%) and the operative goal "Preserved high forest cover with special purpose (virgin forests, forest reserves, protective forests) and establishment of eco cells network" (13.1\%). The results show that stakeholders are interested in Pohorje Park, which will be able to protect the wider Pohorje area. Other operative goals have similar weights: "Restored and preserved water system in Pohorje swamps and waters", "Restored effective control of nature protection for activities in Pohorje", "Working fund for nature protection in Pohorje", "Preserved landscape patterns of Pohorje", and "Restored and preserved Pohorje plains".

The most important operative goal for the strategic goal "Sustainable tourism and limited visit" is "Quality and coordinated supply of local products". It is followed by the operative goal "Identified brand of sustainable destination Pohorje". The operative goal "Qualitative and coordinated supply of local products" was placed third. The last two places went to "Locally conditioned and zoned sustainable capacities and activities in Pohorje" and to the operative goal "Restored conditions for integral experience of nature and cultural heritage
Slika 3: Uteži strateških ciljev

of Pohorje". The results show the importance of being aware that the supply of local products can be a stimulus in the future development of Pohorje.

Regarding the strategic goal "Environmental and consumer friendly usage of natural resources", the most important operative goal is "Development of products from local natural resources and brands with name Pohorje" with the weight of $18.2 \%$, which is much higher than the weights of other operative goals. This operative goal is linked to the most important operative goals of the strategic goal "Sustainable tourism and limited visit", which consolidates its importance. Concerning the importance, the operative goal "Development of products from local natural resources and brands with name Pohorje" is followed by the operative goal "Environmental-friendly and sustainable use of water and water supplies as a source of drinkable water", then by the operative goal "Increased agricultural activity", and finally by the operative goal "Motivated and qualified producers of products from natural resources", which have very similar weights. The next two operative goals are "Enlarged use of energy from available renewable natural resources (biomass, sun, wind) and effective use of energy" and "Increased and effective use of local natural materials for building purposes and as natural sources of food" with just slightly 
Table 4: Priorities of strategic goals, local priorities and ranking of operative goals
Preglednica 4: Uteži strateških ciljev, lokalne uteži in rangi operativnih

\begin{tabular}{|c|c|c|c|c|}
\hline strategic goals & weights & operative goals & local weights & rank \\
\hline \multirow{4}{*}{ High quality life of locals $\left(\mathrm{s}_{1}\right)$} & \multirow{4}{*}{0.162} & 011 & 0.236 & 3 \\
\hline & & 012 & 0.269 & 1 \\
\hline & & 013 & 0.262 & 2 \\
\hline & & 014 & 0.233 & 4 \\
\hline \multirow{8}{*}{ Preserved nature and landscape $\left(\mathrm{s}_{2}\right)$} & \multirow{8}{*}{0.163} & 021 & 0.095 & 8 \\
\hline & & 022 & 0.115 & 5 \\
\hline & & 023 & 0.128 & 3 \\
\hline & & 024 & 0.137 & 2 \\
\hline & & 025 & 0.118 & 4 \\
\hline & & 026 & 0.184 & 1 \\
\hline & & 027 & 0.108 & 7 \\
\hline & & 028 & 0.115 & 6 \\
\hline \multirow{5}{*}{ Sustainable tourism and limited visit $\left(\mathrm{s}_{3}\right)$} & \multirow{5}{*}{0.156} & 031 & 0.165 & 5 \\
\hline & & 032 & 0.217 & 2 \\
\hline & & 033 & 0.182 & 4 \\
\hline & & 034 & 0.247 & 1 \\
\hline & & 035 & 0.190 & 3 \\
\hline \multirow{7}{*}{$\begin{array}{l}\text { Environmental and consumer friendly } \\
\text { usage of natural resources }\left(\mathrm{s}_{4}\right)\end{array}$} & \multirow{7}{*}{0.181} & 041 & 0.088 & 7 \\
\hline & & 042 & 0.154 & 3 \\
\hline & & 043 & 0.133 & 6 \\
\hline & & 044 & 0.134 & 5 \\
\hline & & 045 & 0.182 & 1 \\
\hline & & 046 & 0.153 & 4 \\
\hline & & 047 & 0.156 & 2 \\
\hline \multirow{3}{*}{$\begin{array}{l}\text { Environmental and consumer friendly } \\
\text { mobility and good infrastructure }\left(\mathrm{s}_{5}\right)\end{array}$} & \multirow{3}{*}{0.133} & 051 & 0.324 & 2 \\
\hline & & 052 & 0.365 & 1 \\
\hline & & 053 & 0.312 & 3 \\
\hline \multirow{3}{*}{$\begin{array}{l}\text { Preserved cultural heritage and local } \\
\text { tradition }\left(\mathrm{s}_{6}\right)\end{array}$} & \multirow{3}{*}{0.205} & 061 & 0.388 & 1 \\
\hline & & 062 & 0.223 & 3 \\
\hline & & 063 & 0.388 & 1 \\
\hline
\end{tabular}

smaller weights. The very least important operative goal is "Realized cut of timber, allowed with forest economic plans and reduction of overgrown areas and restored traditional agricultural use of Pohorje plains", which shows that prevention of agricultural areas becoming overgrown does not seem particularly important to the stakeholders.

When analyzing the strategic goal "Environmental and consumer friendly mobility and good infrastructure" we can see that all its operative goals have similar weights. The highest weight was given to the operative goal "Modernized and maintained traffic infrastructure and quality public traffic", followed by the operative goal "Accepted and implemented interregional and local plans of traffic connections", and by the operative goal "Good traffic connections for visitors from low- land to the tourist centres with alternative kinds of transport".

In relation to the strategic goal "Preserved cultural heritage and local tradition", equal weights (38.8\%) were given to the operative goals "Preservation of characteristics of local architecture" and "Connected local and regional events linked with cultural heritage", while the operative goal "Taking advantage of the potential for development of cultural heritage and local tradition" was placed third.

Overall ranking of all operative goals is not reasonable, since the strategic goals "Preserved cultural heritage and local tradition" and "Environmental and consumer friendly mobility and good infrastructure" are connected to only three operative goals. Their weights are, therefore, obviously higher, as for example the 
weights of eight operative goals connected to the strategic goal "Preserved nature and landscape".

\section{CONCLUSIONS}

\section{ZAKLJUČKI}

The aim of our study was to rank the strategic and the operative goals set for sustainable development of Pohorje, Slovenia. We applied AHP, which is a suitable multi-criteria decision making method, widely used for ranking objects. For the aggregation of opinions of five stakeholders we employed geometric mean method that preserves reciprocity, which is an important property in AHP.

First ranking of strategic goals regarding their contribution to the fulfilment of the "Pohorje 2030" vision was performed. Results show that the most important strategic goals are "Preserved cultural heritage and local tradition" and "Environmental and consumer friendly usage of natural resources". Much effort should be invested in their achievement, although other strategic goals should not be ignored, as their weights are not negligible. Only the implementation of all strategic goals in all their extension could assure fulfilment of the "Pohorje 2030" vision.

Each strategic goal is divided into more operative goals, which can fulfil the set strategies in more details. We ranked them according to the appertaining strategic goals. Overall ranking of all operative goals is not reasonable, since their weights are not comparable.

\section{POVZETEK}

\section{SUMMARY}

Gospodarjenje z gozdom je bilo svojčas naravnano predvsem na optimiranje lesne proizvodnje. V zadnjem času pa se vse bolj zavedamo, da gozd nima samo ekonomske vrednosti, marveč tudi naravno, kulturno, ekološko in socialno. Zato je potrebno trajnostno gospodarjenje, ki bo zaščitilo vrednost okolja in skrbelo za ravnovesje med vsemi gozdnimi funkcijami (Sheppard in Meitner, 2005).

Različne poglede in preference lahko vključimo v problem prek različnih deležnikov. Participatorne metode lahko povežemo z večkriterijskim odločanjem in s tem zagotovimo večjo transparentnost in formalnost modela. $V$ raziskavi smo uporabili analitični hierarhični proces (AHP), ki je zelo razširjena večkriterijska metoda in je namenjena razvrščanju in izbiranju optimalne strategije glede na izbrani cilj in kriterije. AHP je bil uporabljen $\mathrm{v}$ več aplikacijah s področja naravnih virov (Blackstock in sod., 2007), trajnostnega razvoja (Srdjevic in sod., 2007), upravljanja z okoljem (Carpenter in sod., 2009; Costanza, 2006; Zendehdel in sod., 2008) in gospodarjenja z gozdom (Kangas in Kangas, 2005; Sheppard in Meitner, 2005; Wolfslehner in Seidl, 2010).

Pohorje je pogorje v Sloveniji, ki je večinoma pokrito z gozdovi iglavcev. Varovano je v okviru Alpske konvencije, velik del pa spada pod območje Natura 2000. Njegov gospodarski razvoj je poleg z gozdarstvom povezan tudi s kmetijstvom in turizmom. Negativni vplivi v zadnjem času nočno ogrožajo Pohorje in njegovo vrednost, zato je nujen skupen načrt upravljanja za ohranitev okolja. Na Pohorju je potekal projekt NATREG (NATREG, 2011b), katerega cilj je bil predlog načrta upravljanja Pohorja. Na podlagi več študij, analize deležnikov, sektorskih delavnic in SWOT-analiz so napisali vizijo »Pohorje 2030« (Hojnik, 2011), izbrali strateške in operativne cilje (NATREG, 2011a), ki naj bi prispevali k njeni uresničitvi, in izdelali akcijski načrt (Stare in sod., 2011).

Cilj raziskave je bil razvrstitev strateških ciljev glede na njihov prispevek $\mathrm{k}$ uresničitvi vizije »Pohorje 2030 « in operativnih ciljev glede na pripadajoči strateški cilj. Za parne primerjave ciljev med seboj smo uporabili metodo analitičnega hierarhičnega procesa. Individualne ocene smo združili v skupno oceno z geometrijsko sredino .

Rezultati kažejo, da je najpomembnejši strateški cilj »ohranjena kulturna dediščina in lokalna izročila« z utežjo 20,5 \%. Na drugem mestu je cilj »okolju in uporabniku prijazna raba naravnih virov« z 18,1 \%. Temu sledijo trije cilji z zelo podobnimi utežmi: »ohranjena narava in krajina«, »visoka kakovost življenja lokalnega prebivalstva« in »sonaravni turizem in usmerjen obisk«. Najmanjšo utež je dobil strateški cilj »okolju in uporabniku prijazna mobilnost ter urejena prometna infrastruktura«, in sicer 13,3 \%. Razlika med prvo razvrščenim in zadnjim ciljem je le $7 \%$, kar kaže, da so deležnikom pomembni vsi izbrani strateški cilji in je samo z uresničenjem vseh ciljev možno uresničiti vizijo »Pohorje $2030 \ll$.

Pri vsakem strateškem cilju smo po pomembnosti razvrstili tudi pripadajoče operativne cilje. Razvrstitev vseh operativnih ciljev skupaj ni smiselna, saj njihove uteži zaradi različnega števila operativnih ciljev pri različnih strateških ciljih niso primerljive med seboj.

\section{REFERENCES}

6 VIRI

Ananda J., Herath G. 2003. The use of analytic hierarchy process to incorporate stakeholder preferences into regional forest planning. Forest policy and economics, 5, 1: 13-26.

Ananda J., Herath G. 2008. Multi-attribute preference modelling and regional land-use planning. Ecological economics, 65, 2: 325335. 
Ananda J., Herath G. 2009. A critical review of multi-criteria decision making methods with special reference to forest management and planning. Ecological economics, 68, 10: 2535-2548.

Belton V., Stewart T. J. 2002. Multiple Criteria Decision Analysis: An integrated approach. (ur.) Norwell, Massachusetts, Kluwer Academic Publishers: 372 str.

Blackstock K. L., Kelly G. J., Horsey B. L. 2007. Developing and applying a framework to evaluate participatory research for sustainability. Ecological economics, 60, 4: 726-742.

Bryan B., Grandgirard A., Ward J. 2010. Quantifying and exploring strategic regional priorities for managing natural capital and ecosystem services given multiple stakeholder perspectives. Ecosystems, 13, 4: 539-555.

Carpenter S. R., Mooney H. A., Agard J., Capistrano D., DeFries R. S.in sod. 2009. Science for managing ecosystem services: beyond the millennium ecosystem assessment. Proceedings of the national academy of sciences, 106, 5: 1305-1312.

Cortés-Aldana F. A., García-Melón M., Fernández-de-Lucio I., Aragonés-Beltrán P., Poveda-Bautista R. 2009. University objectives and socioeconomic results: a multicriteria measuring of alignment. European journal of operational research, 199, 3: 811-822.

Costanza R. 2006. Thinking broadly about costs and benefits in ecological management. Integrated environmental assessment and management, 2, 2: 166-173.

Diaz-Balteiro L., Romero C. 2008. Making forestry decisions with multiple criteria: A review and an assessment. Forest ecology and management, 255, 8-9: 3222-3241.

Duke J. M., Aull-Hyde R. 2002. Identifying public preferences for land preservation using the analytic hierarchy process. Ecological economics, 42, 1-2: 131-145.

Kangas J., Kangas A. 2005. Multiple criteria decision support in forest management--the approach, methods applied, and experiences gained. Forest ecology and management, 207, 1-2: 133-143.

Lee A. H. I., Chen H. H., Kang H.Y. 2009. Multi-criteria decision making on strategic selection of wind farms. Renewable energy, 34 , 1: $120-126$.

Mendoza G. A., Prabhu R. 2006. Participatory modeling and analysis for sustainable forest management: Overview of soft system dynamics models and applications. Forest policy and economics, 9, 2: 179-196.

NATREG. 2011b. NATREG - Managing Natural Assets and Protected Areas as Sustainable Regional Development Opportunities Ljubljana, Zavod RS za varstvo narave

http://www.natreg.eu/pohorje/
Nordström E.-M., Eriksson L. O., Öhman K. 2010. Integrating multiple criteria decision analysis in participatory forest planning: Experience from a case study in northern Sweden. Forest policy and economics, 12, 8: 562-574.

Nordström E.-M., Romero C., Eriksson L. O., Ohman K. 2009. Aggregation of preferences in participatory forest planning with multiple criteria: an application to the urban forest in Lycksele, Sweden. Canadian journal of forest research, 39, 10: 1979-1992.

Pavlikakis G. E., Tsihrintzis V. A. 2003. A quantitative method for accounting human opinion, preferences and perceptions in ecosystem management. Journal of environmental management, 68, 2: 193-205

Rowe G., Frewer L. J. 2000. Public participation methods: a framework for evaluation. Science, technology \& human values, 25, 1: 3-29.

Saaty T. L. 1980. The analytic hierarchy process. (ur.) New York, McGraw-Hill: 287 str.

Saaty T. L. 2006. Fundamentals of decision making and priority theory with the analytic hierarchy process. (ur.) Pittsburgh, RWS Publications: 478 str.

Sheppard S. R. J., Meitner M. 2005. Using multi-criteria analysis and visualisation for sustainable forest management planning with stakeholder groups. Forest ecology and management, 207, 1-2: 171-187.

Srdjevic Z., Kolarov V., Srdjevic B. 2007. Finding the best location for pumping stations in the Galovica drainage area of Serbia: the AHP approach for sustainable development. Business strategy and the environment, 16, 7: 502-511

Sun J., Li H. 2009. Financial distress early warning based on group decision making. Computers \& operations research, 36, 3: 885906.

Wang Y.-M., Chin K.-S. 2009. A new data envelopment analysis method for priority determination and group decision making in the analytic hierarchy process. European journal of operational research, 195, 1: 239-250.

Weintraub A., Romero C., Bjørndal T., Epstein R. 2007. Handbook of operations research in natural resources. (ur.) Berlin, Springer: 614 str.

Wolfslehner B., Seidl R. 2010. Harnessing ecosystem models and multi-criteria decision analysis for the support of forest management. Environmental management, 46, 6: 850-861.

Zendehdel K., Rademaker M., De Baets B., Van Huylenbroeck G. 2008. Qualitative valuation of environmental criteria through a group consensus based on stochastic dominance. Ecological economics, 67, 2: 253-264. 